\title{
Households' Consumption of Electrical and Electronic Equipment and Environmental Implication in Ota, Nigeria
}

\author{
Nathaniel Oluwaseun Ogunseye \\ Department of Urban and Regional Planning, Olabisi Onabanjo University, Nigeria \\ Email: townplannerseun@yahoo.com \\ DOI//http://dx.doi.org/10.4314/gjds.v16i3.1
}

\begin{abstract}
The generation of waste electrical and electronic equipment (WEEE) has been attributed to unprecedented consumption of electrical and electronic equipment (EEE) globally. Hence, the issue of consumption and management of the associated WEEE warrant investigation. This study seeks to provide insight into households' consumption of EEE in Ota, Nigeria. Multistage sampling technique was used to purposely administer questionnaire on 111 households' heads/representatives in random manner. Data collected were analysed using both descriptive and inferential statistics. The findings indicated that rate in EEE consumption pattern reflects the appliances' importance to the households. Also, significant proportion of the households (81.5\%) consumed new EEE, implying new EEE is preferred to purchase of used EEE. Decision to acquire new EEE is based on convenience rather than increased income or advertising as reported by 58\%. Households' sale of old EEE appears to suggest reuse or recycling. However, 20.3\% of households threw away old EEE. The Chi-Square Tests revealed that there is statistical relationship between respondents' income and preference to buy, repair or service EEE. This study recommends a holistic approach to research on EEE consumption, review of extant regulations on WEEE management and stakeholders' engagement for inclusive WEEE management.
\end{abstract}

Keywords: Consumption, Electrical and Electronic Equipment, Households, Management, Ota - Nigeria, Waste Electrical and Electronic Equipment

\section{INTRODUCTION}

Globally, there is high demand for electrical and electronic equipment (EEE) (Kalana, 2010; Katagishi et al., 2011; Terada, 2012; Chukwudebe \& Diala, 2014) resulting in increased generation of waste electrical and electronic equipment (WEEE) or e-waste (Perez-Belis, Bovea \& Ibanez-Forez, 2015). More than 40 kilotonnes of e-waste were 
discarded globally in 2014 (Magalini, Kuehr \& Balde, 2015; Kumar \& Holuszko, 2016). The Global e-Waste Monitor reported that Asia generated the greatest quantity of e-waste, approximately 16 million tonnes, followed by America (North America, Central America and South America) with 11.7 million tonnes and Europe with 11.6 million tonnes (Balde et al., 2015). In Nigeria, approximately 1.1 million tonnes of EEE from sources such as households, institutional and corporate consumers become obsolete yearly with 440,000 tonnes ending up as e-waste (Ogungbuyi et al., 2012).

That WEEE management is a global concern (Herat, 2007; Mihai \& Gnoni, 2016; Nnorom \& Osibanjo, 2008; Ogungbuyi et al., 2012; Tong \& Wang, 2012) became clear by the export of WEEE from developed countries to developing countries (Arora, 2008; Perez-Belis et al., 2015). This scenario was linked to stringent legislation on WEEE management operations in developed countries. This illicit act by WEEE exporters was cheaper than complying with the enacted laws. Unfortunately, developing countries lack the technology for WEEE management. Therefore, human health and the environment are negatively affected (Adesina, 2012; Perez-Belis et al., 2015). There are also concerns regarding effects on resource consumption (production and usage) of valuable metals, which are components of EEE (Magalini et al., 2015). Hence, the issue of consumption and management of the associated WEEE warrant investigation.

Whereas previous studies have concentrated on e-waste management, material flow and recycling, the current study focuses consumption of EEE.

The following abbreviations appear severally in previous studies and require elaboration. Electrical and Electronic Equipment (EEE), or home electronics products, are produced for consumers' convenience, comfort and entertainment (Kalana, 2010; Katagishi et al., 2011). These products include television sets, radios, computers, refrigerators, air conditioners and other appliances. Nonetheless, the electronic market offers two versions of EEE: 'new EEE' and 'used EEE' (UEEE) (Manhart et al., 2011; Ogungbuyi et al., 2012). New EEE refers to products coming directly from the manufacturers and not previously used. Conversely, UEEE has been utilised but for some reason was replaced by users although the product remained functional or required refurbishment. It is noteworthy that the waste electrical and electronic equipment (WEEE) or electronic waste or e-waste results from EEE consumption, when the appliances reach their end-of-life.

The literature is diverse on consumption and management of EEE and its waste. The post-war era was described as thrifty (Pitcher, 2015). Corroborating this stance, Glaubitz (2011) posited that in the post-war era, consumer products such as TV 
sets and stereo are not normally replaced except it malfunctions, and servicing of damaged TV set was the norm. But these attitudes have changed during the last quarter of the 2oth century. The current scenario regarding consumer behaviour is referred to as "Throwaway Society" (Enger \& Smith, 2002; Rees, 2009), and is defined as "society in which people do not keep things for long, even if those things still work and are still useful" (Rees, 2009:1). Gutberlet (2003) argued that this behaviour has been bequeathed to the developing countries by the developed countries. And to manage this unsustainable consumption of electronics there is the application of extended producer responsibility (EPR). Currently, EPR is being implemented by the EU, Japan, South Korea, United States (Nnorom \& Osibanjo, 2008), and the Nordic (Stefansdotter et al., 2016). The concept evolved in support of the polluter pay principle and the need to achieve improvement in waste management (recycling) as agreed at the Rio Earth Summit. The EPR advocates that electronics consumers should take responsibility for its recycling in form of higher prices with the assumption that producers and manufacturers will factor the transportation, recycling and disposal costs into product cost during sale (Nnorom \& Osibanjo, 2008).

Studies have been conducted on WEEE management worldwide. Kalana (2010) studied households' e-waste management practices in Shah Alam, Selangor in Malaysia. The findings revealed that residents' preferred methods of e-waste disposal were storage and sale as second-hand equipment. Only 22\% of e-waste gets to recycling facilities because there was no take-back scheme in place, and most households are unaware of proper e-waste disposal. Ojeda-Benitez et al. (2013) examined the waste management practices of WEEE in northwest Mexico and observed that $21 \%$ was disposed of as part of the municipal solid waste stream and $79 \%$ was stored for sale, repair or reuse. Chukwudebe and Diala's (2014) study on the problems of e-waste in Africa revealed a lack of formal recyclers, and most informal recyclers are ignorant of the hazards that e-waste recycling posed to their health and environment. Mburu and Tuduetso (2013) studied consumers' behaviour on discarding e-waste in Botswana, and the results indicated that most people are aware of e-waste and its danger but lack the knowledge to properly discard such items. These studies suggest a lack of knowledge in the community that must be addressed.

In Nigeria, e-waste studies have also focused on e-waste generation, material flow and e-waste recycling. Ibrahim et al. (2014) studied the material flow of the end-of-life equipment in major cities in Nigeria and results revealed that the demand for electronic equipment and e-waste quantity generated will continue to increase. The study revealed the end-of-life options for computer equipment are 
storage, reuse and direct disposal. Manhart et al. (2011) examined socioeconomic impact and feasibility of international recycling co-operations of informal e-waste management in Lagos. They found out that refurbishing, collection and recycling of UEEE take place within and around certain business clusters while majority of refurbished products are imported via Lagos ports. 70\% of the imported UEEE is functional and offered for sale after testing. Again, $70 \%$ of the non-functional UEEE can be repaired and put on sale whereas 9\% of the total imports is non-repairable and is forwarded to collectors and recyclers. Researchers found out that collection and recycling of UEEE are informally driven. Collectors buy old devices for small amount from businesses and private households. Omole et al. (2015) studied factors responsible for increased demand for EEE in Abeokuta and Ota (both in Nigeria). The researchers concluded that economic status is a determinant for EEE demand while the functionality and affordability of EEE motivate consumers' purchases rather than the equipment's durability.

It is noteworthy that most research efforts have dwelt on e-waste management but there is paucity of research regarding consumers' behaviour (consumption of EEE) that results in e-waste generation. There had been attempts at estimating the material flow of e-waste but consumption, which is a crucial stage in life cycle of EEE products needs to be studied if sustainable consumption of EEE is to be achieved. It is on this premise that this paper seeks to understand households' consumption of EEE in Ota, Nigeria. Specific objectives are to assess EEE consumption rate, appraise households' preferences for new EEE and used EEE (UEEE), examine factors influencing EEE consumption, and identify disposal methods for EEE. The paper is divided into four sections. The first section reviews the relevant literature. It is followed by methodological approach to the study, where issues regarding study area, survey instrument, sampling procedure and data analysis are presented. Sections three presents the results as well as discuss the findings. The last section presents the conclusion and recommendations.

\section{METHODOLOGY}

\section{Study Area}

Ota is located in the Ado-Odo/Ota Local Government Area (LGA) of Ogun State in south-western Nigeria (Figure 1). It covers 878 square kilometres (Olukanni, Akinyinka, Ede, Akinwunmi \& Ajanaku, 2014) and lies between the latitude $6^{\circ} 41^{\prime} \mathrm{N}$ and longitude $3^{\circ} 12^{\prime} \mathrm{E}$. One of the fastest growing areas in Ogun State, it has been categorised as a Development Pressure Area within the State (Ogun State Government, 2008). Ota follows Ikeja and Apapa in Lagos State, which are locations 
of industrial concentration in Nigeria. The industrial concentration had led to the migration of people into the area, those seeking employment and those who could not afford the high housing costs in Lagos, with which it shares borders (Salako, 2009). Other migrants in the area include those who provide tertiary services in support of the industries; the proximity of Ota to the Nigeria/Benin Republic Border contributed to the inflow of ECOWAS citizens (Ogunseye \& Kadiri, 2016).

Ota is host to a good number of tertiary institutions: The Bells University of Technology, Ota; Covenant University, Ota; Crawford University, Igbesa; Allover Polytechnic, Ota; the Gateway Institute of Technology, Igbesa; and proposed Ronik Polytechnic, Atan-Ota, consequently it is becoming an important tertiary education hub in Ogun State and the country as a whole.

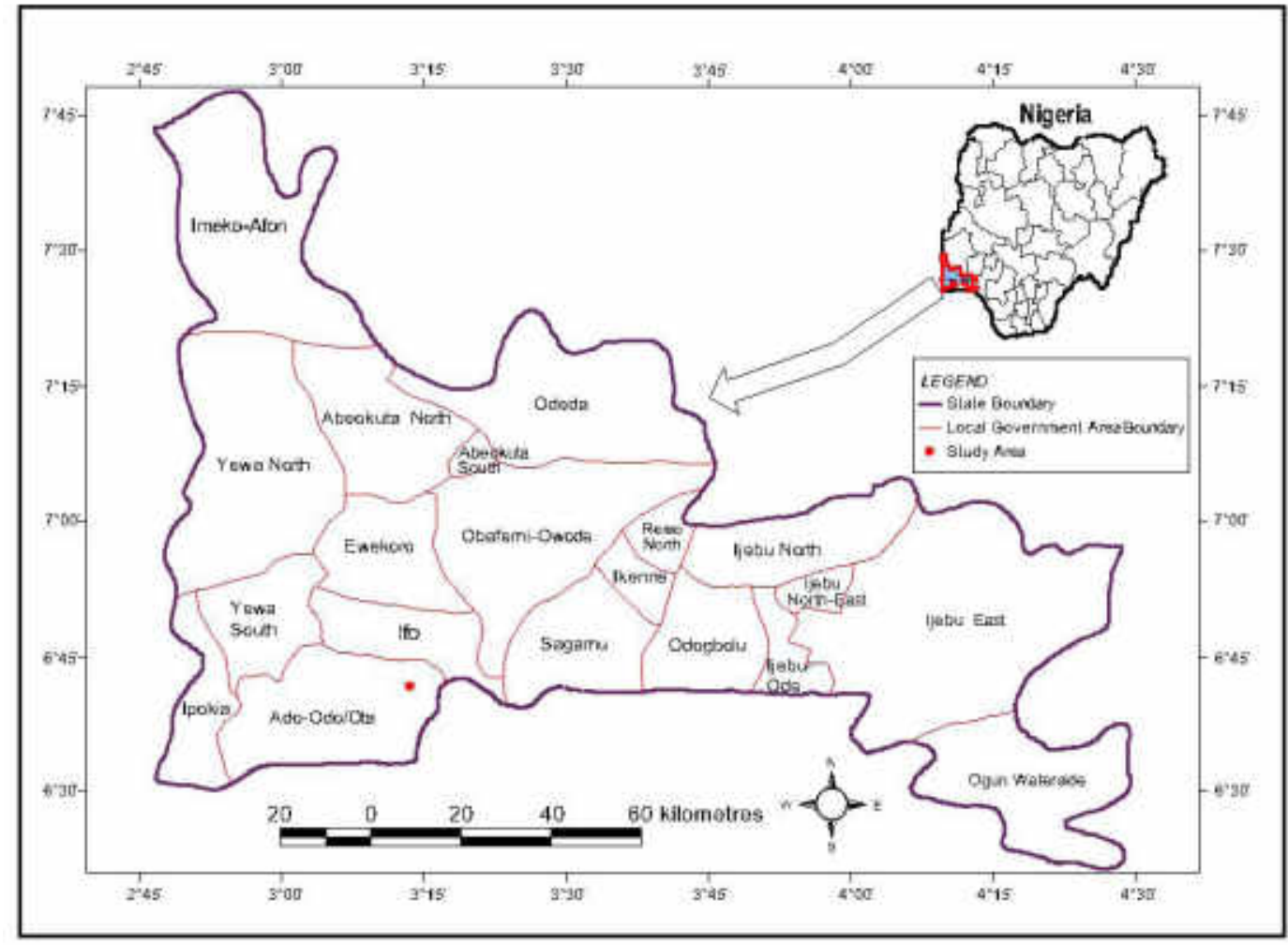

Figure 1: Map of Ogun State in Nigeria showing the study area

\section{Survey Instrument and Sampling Procedure}

This study adopted the structured questionnaire method to elicit data from households regarding the consumption of EEE. This is in accordance to Arora (2008) who noted that a study conducted in Thailand utilised questionnaires in the sampling of e-waste sources such as houses, offices, institutions, hotels 
and apartments, and recyclers regarding electronic products such as televisions, notebooks, air conditioners (ACs), mobile phones and refrigerators. The close-ended questionnaire captures the respondents' socioeconomic characteristics such as gender, age, income, educational level and employment status. Nineteen EEE were identified and selected for consideration: air conditioner, blender, clothes dryer, clothes iron, computer, dishwasher, electric kettle, electric stove, fan, freezer, microwave oven, music player/radio, refrigerator, toaster, television, washing machine, water heater, vacuum cleaner, and voltage stabilizer. The selection was based on the availability of EEE in the Nigerian setting.

In selecting sample for this study, the study area was stratified into eight political wards as approved by the Federal Government. Afterwards, six out of the eight political wards into which Ota (the study area) is divided were randomly selected. The randomly selected six political wards include Ota I, Ota III, Iju, Ijoko, Sango and Atan. Then 20 copies of questionnaire were conveniently distributed in each of the 6 randomly selected political wards and purposely administered to household heads/representative in a systematic manner of every 1oth building. 111 copies of the distributed questionnaire were retrieved for analysis, thus accounting for $93 \%$ response rate (Table 1 ).

Table 1: Questionnaire administration

\begin{tabular}{|l|l|l|l|}
\hline $\begin{array}{l}\text { Political } \\
\text { Ward }\end{array}$ & $\begin{array}{l}\text { Neighbourhood within } \\
\text { political ward }\end{array}$ & $\begin{array}{l}\text { Number of } \\
\text { Questionnaire } \\
\text { Distributed }\end{array}$ & $\begin{array}{l}\text { Number of } \\
\text { Questionnaire Retrieved }\end{array}$ \\
\hline Ota I & Ewupe & 20 & 19 \\
\hline Ota III & Ilo-Awela & 20 & 18 \\
\hline Ijoko & Ijoko & 20 & 19 \\
\hline Iju & Benja & 20 & 20 \\
\hline Atan & Atan & 20 & 19 \\
\hline Sango & Sango & 20 & 16 \\
\hline Total & & $\mathbf{1 2 0}$ & $\mathbf{1 1 1}$ \\
\hline
\end{tabular}

\section{Data Analysis}

Data collected were analysed using both descriptive and inferential statistics with the aid of statistical analytical tool called Statistical Package for Social Sciences version 16. For descriptive analysis, the frequencies of households' responses to each question on every appliance under consideration were obtained. Subsequently, the results of the analysis were imported to Microsoft Excel, Office 2013 to generate 3-D stacked bar charts for data presentation. Inferential statistics involving Chi- 
Square Tests (Pearson Chi-Square Test and Fisher's Exact Test) were conducted to examine associated relationship between socio-economic variables (educational level and income) and independent variable (preference to buy, service or repair EEE).

\section{Hypothesis Testing}

Two hypotheses were formulated and tested to establish an associated relationship between socio-economic variables (educational level and income) and independent variable (preference to buy, service or repair EEE). They are:

i. Ho: There is no statistical relationship between level of education and preference to buy, service or repair EEE

ii. Ho: There is no statistical relationship between income and preference to buy, service or repair EEE

\section{RESULTS AND DISCUSSION}

\section{Socio-economic Characteristics of Respondents}

Results revealed that $56.8 \%$ of the respondents are male while $43.2 \%$ are female. The age of respondents indicated that majority (72.9\%) fell within the age group of 21 and 50 years. This is possible especially when it is considered that the study is adult-based. A majority (96.4\%) of the respondents is literate, having obtained one academic qualification or another. That majority of the respondents are literate may have also influenced their employment status, a situation where $13.5 \%$ are civil servants, $25.2 \%$ private employees and $44.1 \%$ self-employed. This result may therefore support the fact about industrial concentrations in Ota (the study area), and the fact that it accommodates the population who work in Lagos but reside in Ota because it provides affordable rental when compared to the situation in Lagos. As for the monthly income, results revealed $14.4 \%$ of respondents earned below $\mathrm{N} 18$,000 (US\$57.50) (the national minimum wage), about 49\% take home between $\mathrm{N} 18,000$ and $\mathrm{N} 60,000$ and $20.7 \%$ earned above 16000 , thus suggesting that significant proportion of respondents have the capacity to consume EEE for various reasons. 


\section{Total Consumption of EEE}

Television is the most common EEE, used by $85.6 \%$ households. The percentages of household consumption for other EEE are clothes iron (82.0\%), fan (80.2\%), music player/radio (67.6\%), blender (60.4\%), voltage stabilizer (58.6\%), electric stove (55.0\%), computer (50.5\%), freezer (50.5\%), refrigerator (50.5\%), electric kettle (49.6\%), toaster (38.7\%), washing machine (37.8\%), microwave oven (29.7\%), water heater $(25.2 \%)$, air conditioner (24.3\%), clothes dryer (21.6\%) and vacuum cleaner (18.0\%). The least consumed EEE was the dishwasher, used by $16.2 \%$ of households.

Appliances such as freezers and refrigerators were expected to be in high demand because the study area is in the tropics. However, similarities in their functions appear to have influenced households' consumption rate. Similarly, the results indicated that households used fewer air conditioners (ACs) than fans. This greater consumption of fans can be linked to their functionality as a less expensive substitute to acquire and use. Generally, the variations in the households' EEE consumption pattern reflects the appliances' importance to the households.

\section{Consumption of New EEE and UEEE}

Figure 2 presents the relative percentage of new EEE and UEEE used at the household level. In general, for the $19 \mathrm{EEE}, 81.5 \%$ (mean percentage) of households utilised new EEE, and $18.5 \%$ used UEEE. However, the results revealed that the mean percentage (70.1\%) of households bought 'new EEE' whereas $11.4 \%$ of households obtained EEE as gifts. For the UEEE, the mean percentage (12.6\%) of households bought EEE whereas $5.9 \%$ of households received them as gifts. The predominance of new EEE acquisition amongst households suggests households' confidence in acquiring new EEE compared with UEEE. Moreover, this result contrasts with Adesina's (2012) position that UEEEare popular amongst Nigerians because they are cheaper and durable than new EEE. 


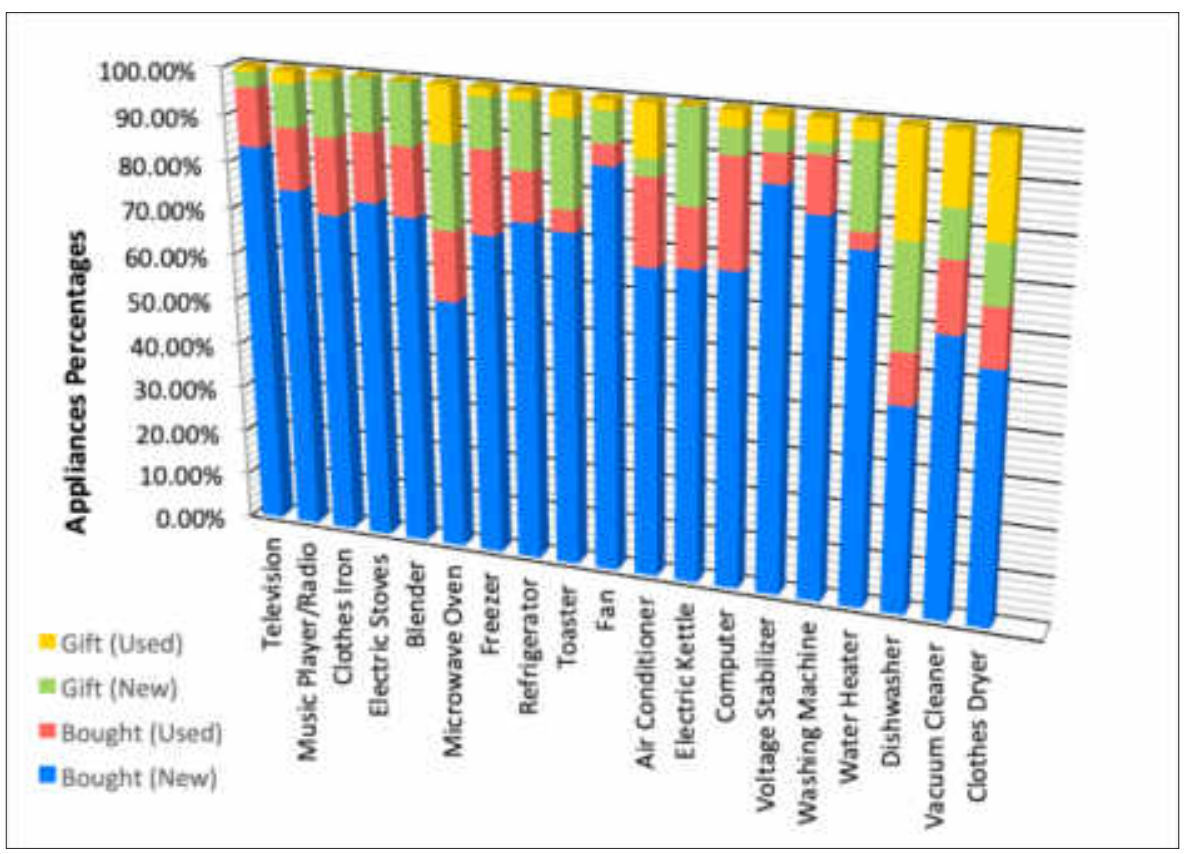

Figure 2: Consumption of new EEE and UEEE

Source: Author's Field Survey, 2016

\section{Condition Rating of EEE}

Figure 3 demonstrates that $68.6 \%$ (mean percentage) of households rated their EEE as 'good', 22.6\% rated theirs as 'fair' and 8.8\% said their EEE was in 'poor' condition. The results of condition ratings may be linked to a greater proportion of households who owned new EEE (Figure 2). In addition, amongst households, television represented the highest percentage (88.9\%) of the EEE in 'good' condition whereas air conditioners represented the lowest (52.0\%). For the EEE rated 'fair' by households, air conditioners were rated highest (36.0\%) and televisions lowest (10.0\%). For the EEE rated poor, microwave ovens were rated highest $(21.2 \%)$ and toasters the lowest with $0.9 \%$.

However, households' condition ratings revealed some contradictions. For example, $70 \%$ rated their dishwasher as 'good' although approximately $40 \%$ of households bought a used dishwasher. This result suggests that some of the used dishwashers were in good condition despite being second-hand equipment. Clearly, not all UEEE is in poor condition. This result is consistent with study of Ogungbuyi et al. (2012), who noted that there was good quality UEEE. 


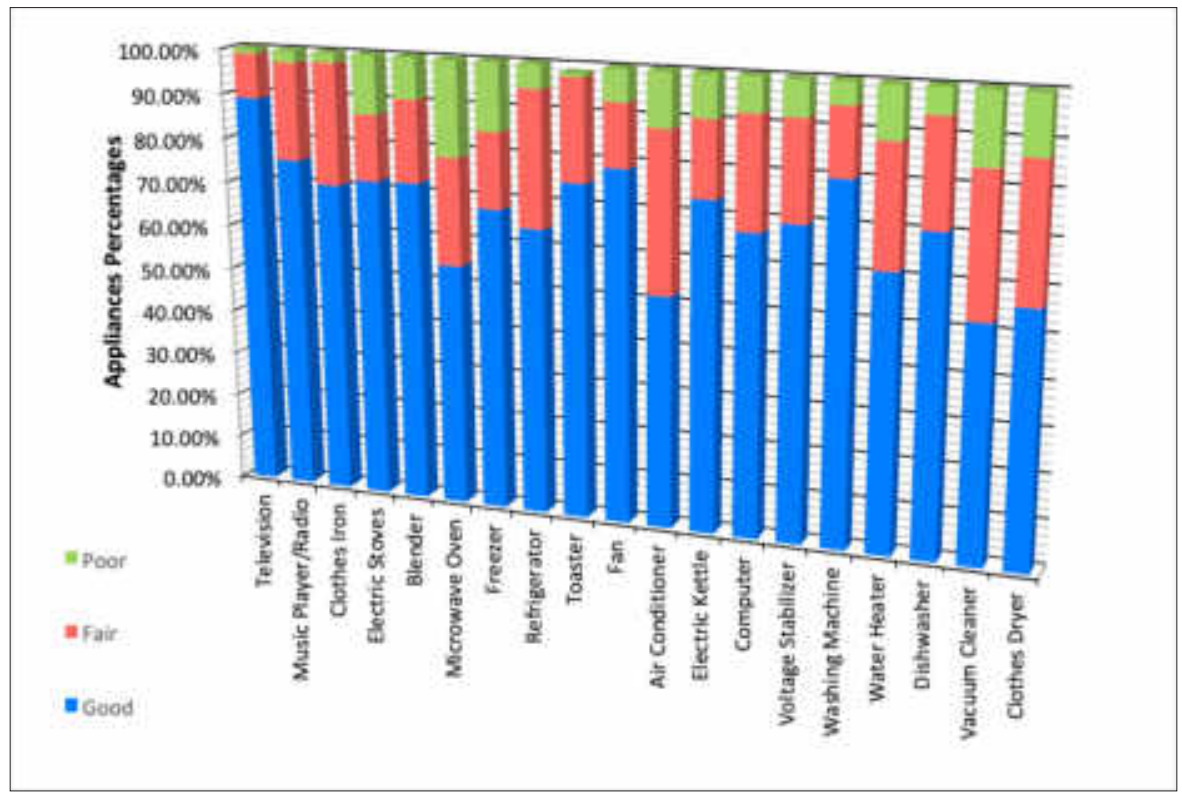

\section{Figure 3: Condition rating of EEE}

Source: Author's Field Survey, 2016

Similarly, over $60 \%$ of households claimed to have bought 'new' ACs, yet only $52 \%$ affirmed that they were in good condition. This is quite possible because the AC may have malfunctioned between 'purchase time' and 'study time' (when this study was conducted).

Although appliances rated 'fair' and 'poor' are likely to have reached the end or near the end of their usefulness, it is imperative to provide for their disposition; otherwise, they soon become part of the waste stream resulting in pollution and causing harm to people and the environment. These results regarding conditionratings of EEE are significant because they help policy makers and waste managers forecast or estimate the quantity of EEE requiring management in the near future.

\section{Preferences to Buy, Service or Repair EEE}

The results indicated that households' preferences for buying, servicing or repairing EEE are $45.9 \%, 25.2 \%$ and $28.9 \%$, respectively. Although majority of households claim that their UEEE is in good condition (Figure 3), the results (Figure 4) indicated that approximately $46 \%$ of households prefer to buy new EEE rather than to service or repair what they already have if it malfunctions. This is fair compared to result of a survey in the Britain, where $69 \%$ of respondents preferred to dispose of their malfunctioned EEE including those that are of relatively high value (Pitcher, 2015). However, the results suggest a "throwaway society" is replicating itself in the study 
area (Ota), thus affirming the stance of Gutberlet (2003) that it is being handed down by the developed countries to the developing countries.

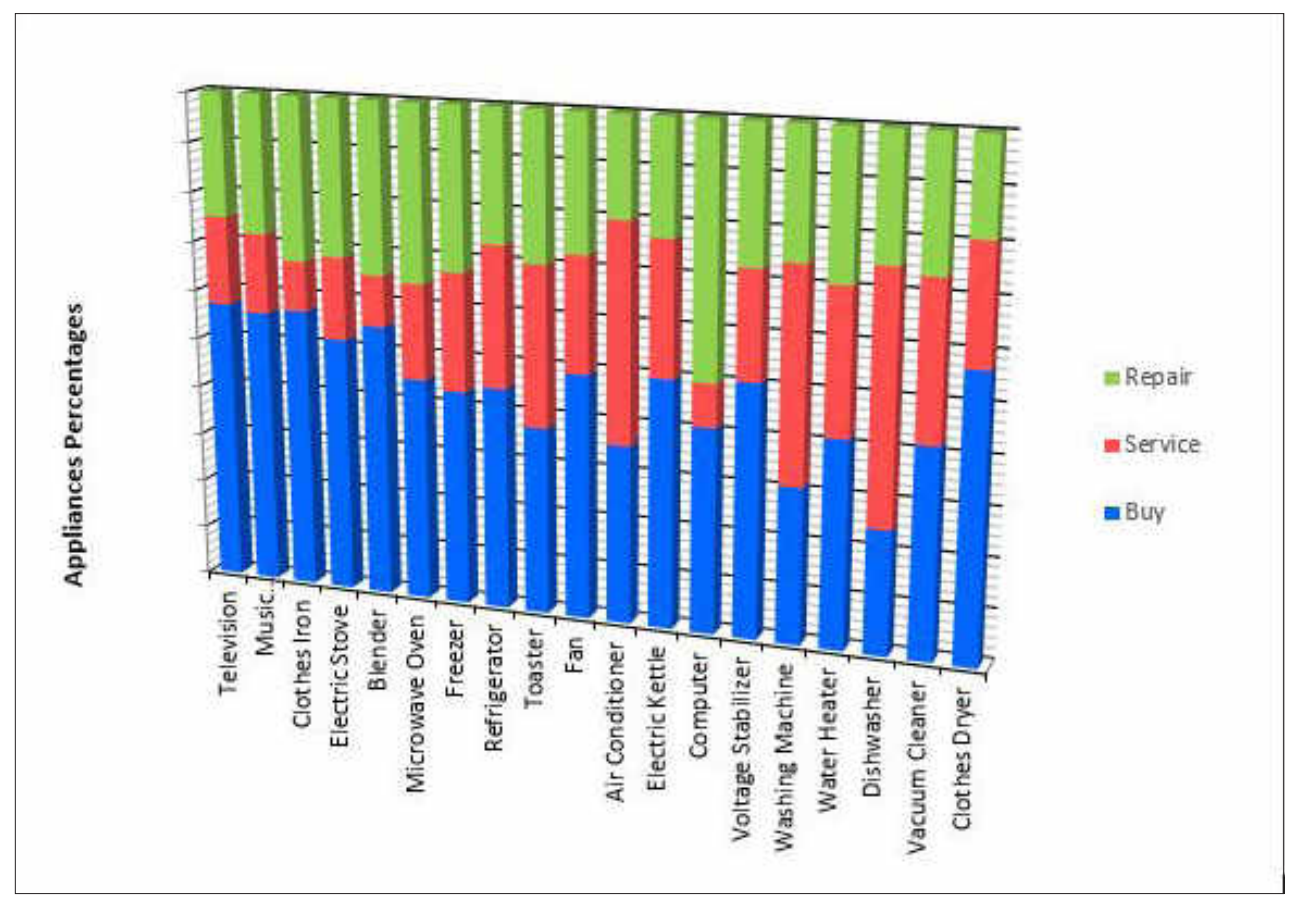

Figure 4: Preferences to buy, service or repair EEE

Source: Author's Field Survey, 2016

The servicing of EEE by households was also a priority for appliances such as air conditioners (44.0\%), washing machines (42.9\%) and dishwashers (50.0\%), which may be because of the higher replacement costs of their acquisition compared with other EEE. In addition, 50.0\% of households gave priority to computer repair over replacing or servicing.

Additionally, it can be deduced from households' preferences that EEE consumption is not sustainable, with only 54\% preferring to service or repair. Unless the servicing and repairing of malfunctioning EEE are given priority and practised by households, an increase in e-waste becomes inevitable. From a sustainable consumption perspective, servicing and repairing EEE are preferable to buying new EEE. These approaches to managing malfunctioning EEE support the sustainable waste management tenets of waste reduction, reuse and recycling.

\section{Determinants of EEE Consumption}

Figure 5 presents factors that influence households' EEE consumption. The mean percentage $(58.0 \%)$ of households claimed convenience to be a factor for EEE 
consumption. The other factors, in order of significance, were as follows: relatives (10.2\%), friends (10.1\%), advertising (9.4\%), increased income (9.0\%), and neighbours (5.4\%). The results indicated that relatives and friends have greater influence than advertising and increased income on EEE consumption. The results also suggest that first-hand information, based on experiences of relatives and friends, can be a major factor influencing households' decisions regarding EEE consumption. Thus, affordability and advertising are less significant factors than convenience. This is in contrast to study by Omole et al. (2015) that revealed that affordability is an important determinant of increased demand for EEE. Notably, an exception was observed in the case of dishwashers, with $37.5 \%$ households considering advertising to be a key factor. Household conveniences should not be taken for granted, and efforts to make households realise the severity of the environmental effects of EEE consumption in the near future must be balanced with the immediate satisfaction derived from EEE consumption. The continual acquisition and consumption of EEE without organised disposal methods after use do not augur well for either human health or the environment. It can also be deduced that people (consumers) would be key to creating awareness of the environmental impact of WEEE because $25.7 \%$ of households confirmed roles played by their relatives, friends and neighbours concerning EEE consumption. Policy makers should take advantage of this by disseminating vital information to the public regarding the risks associated with unsustainable EEE consumption.

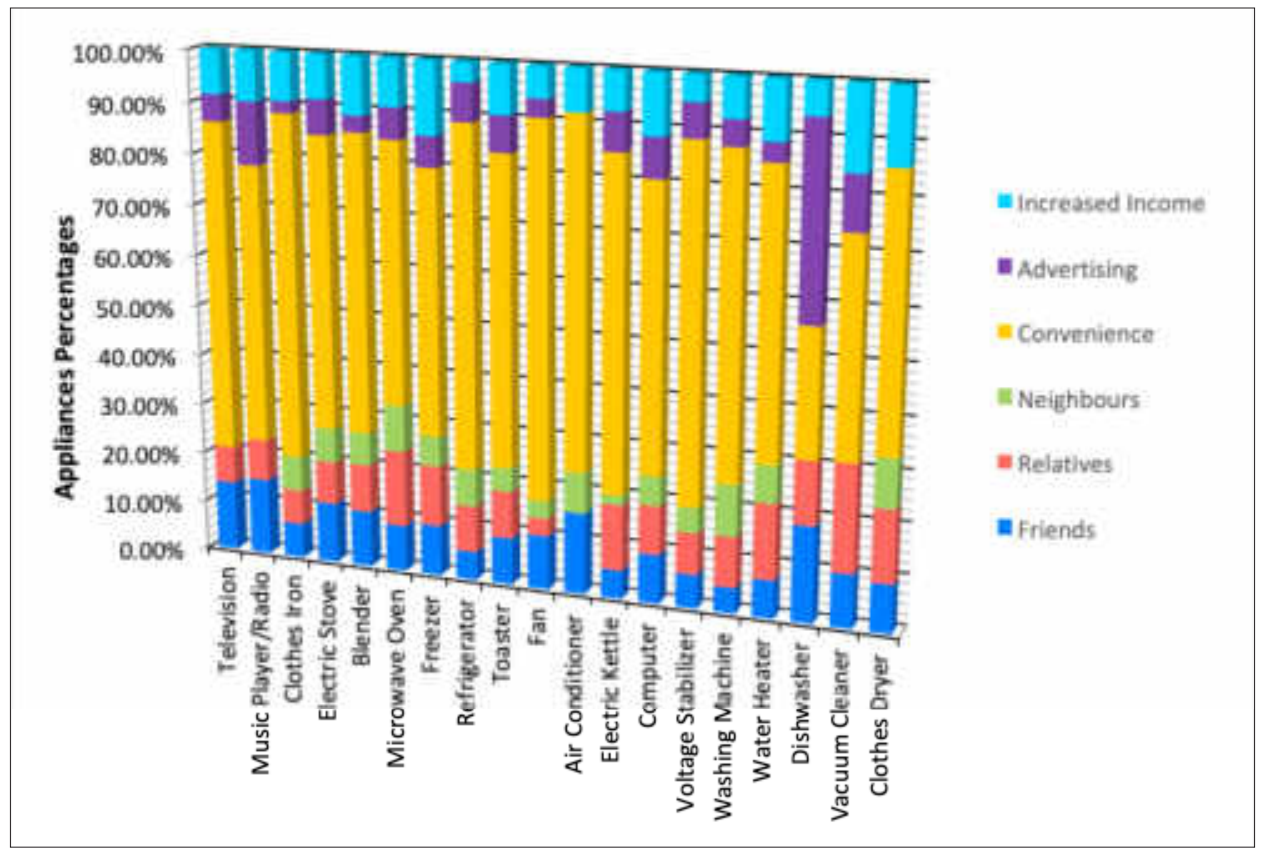

Figure 5: Determinants of EEE consumption

Source: Author's Field Survey, 2016 


\section{Period of Ownership}

Figure 6 presents the period of ownership of the EEE. Of the households, $54.9 \%$ acquired EEE between 1-2 years ago; the next group of $24.6 \%$ of households acquired their EEE between 3 and 5 years ago. In addition, 12.0\% acquired their EEE less than one year ago, and $7.5 \%$ claimed between 6 and 10 years. Households with more than 10 years are marginal and constitute $0.6 \%$ for between 11 and 15 years, and $0.4 \%$ for above 15 years.

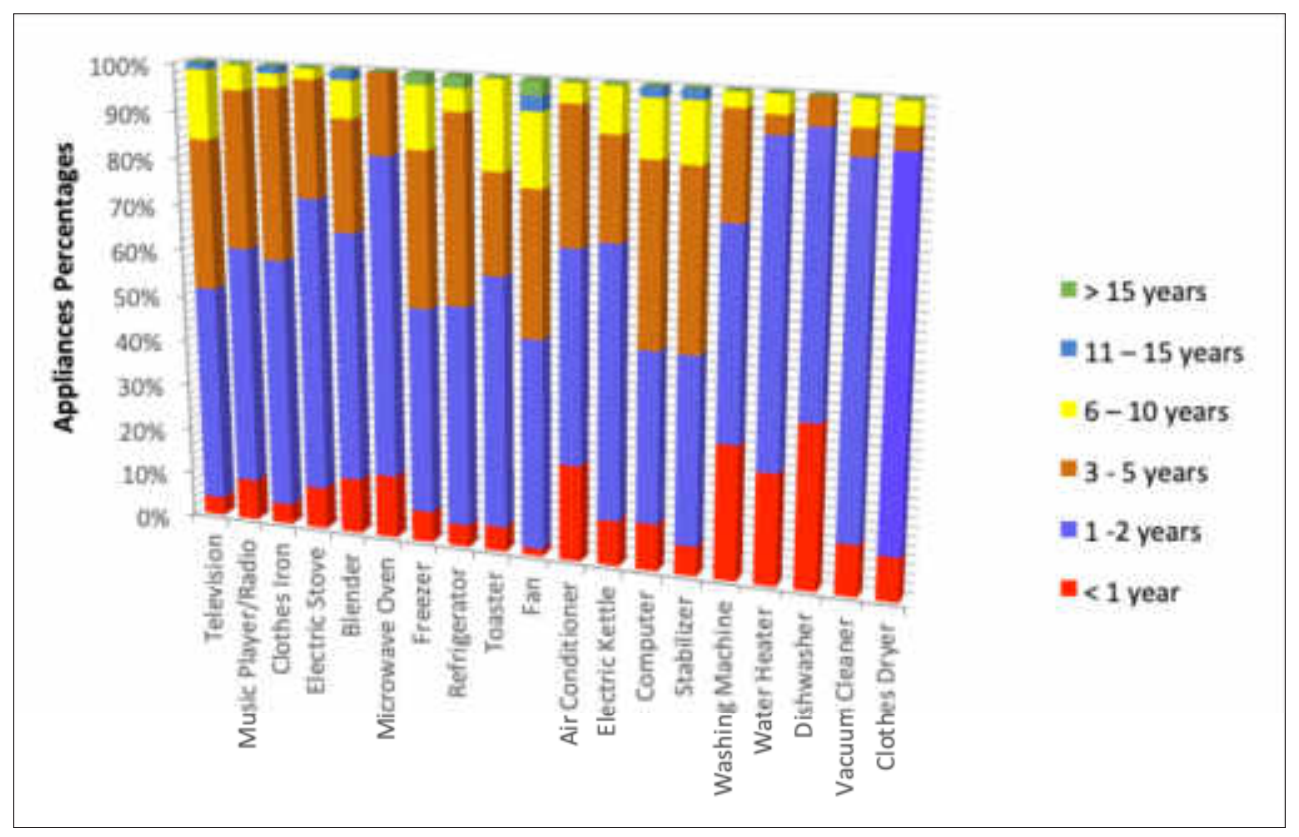

\section{Figure 6: Period of ownership}

\section{Source: Author's Field Survey, 2016}

It can be deduced that the majority (91.5\%) of households acquired and have been consuming EEE for approximately five years although greater consumption was witnessed between 1-2 years (between 2014 and 2016). Researchers reported that the useful life of EEE is becoming shorter (Arora, 2008; Carchia cited in Chukwudebe \& Diala, 2014; Veit \& Bernades, 2015). Joines (2012) opined that the probability of consumers' replacing 2-3-year-old EEE with new equipment is greater than the probability of having them upgraded. Considering the researchers' position on the average useful life of EEE, Ota should expect an increase in the WEEE generation rate. Unless this envisaged growth is planned for, the effects of WEEE on human health and the environment are imminent. This is because Ota presently does not have an operational waste management system that could cater for WEEE that enters the waste stream. 


\section{Method of Disposal}

This study also probed into what occurred to the previous EEE (old EEE) when the households obtained their current EEE (new EEE or UEEE). The results detailed in Figure 7 indicate that the mean percentage (52.2\%) of households obtained EEE for the first time and thus had no issues with disposing of old EEE. Of the households, 12.6\% were involved in the sale of 'old EEE' from their homes, suggesting some sort of reuse or recycling. In addition, $14.2 \%$ of households offered old EEE as gifts, and $0.7 \%$ of households retained old EEE for occasional use. About $20.3 \%$ households threw away their old EEE, implying that households considered that the appliance was not sufficiently valuable to sell, reuse, or present as a gift.

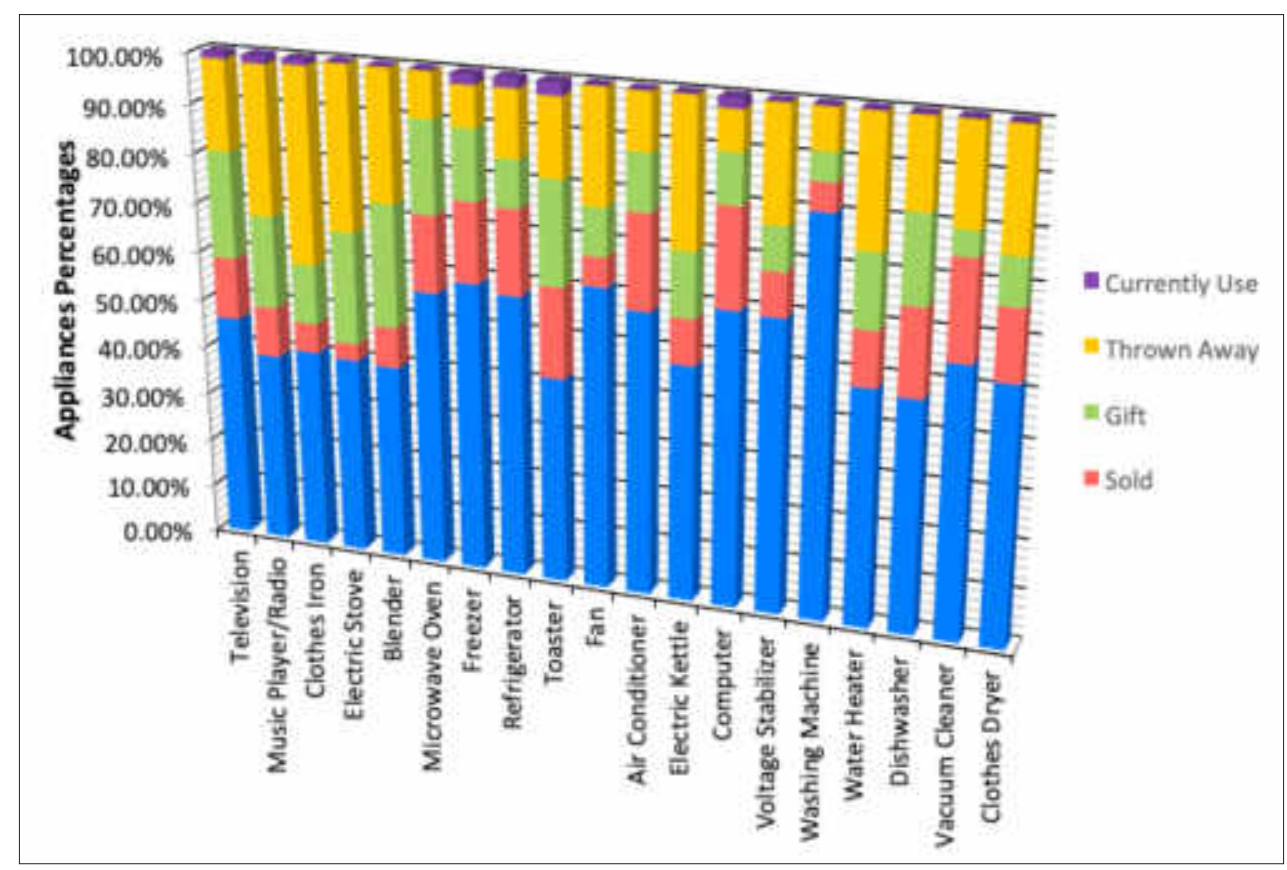

Figure 7: Method of disposal

Source: Author's Field Survey, 2016

This "throwing away" attitude towards old EEE is an unethical approach to WEEE management and must be discouraged because of the negative effects of WEEE when disposed of and mingled with other waste materials. Studies (Adesina, 2012; Herat, 2009; Mihai \& Gnoni, 2016; Terazono et al., 2006) established that EEE contains toxic materials, and if not properly disposed of, contaminates the environment and is harmful to humans. The results support Ogungbuyi et al.'s (2012) study in Lagos, Nigeria that posits that consumers disposed of UEEE, stored some portions, gave out as donation or gift, and sold to repair or refurbishment shops. Results also corroborate the studies by Herat (2009) focusing on "current end-of-life 
management of e-waste in Australia" regarding used computers, and Ibrahim et al. (2014) who studied the material flow of end-of-life computer equipment in three major cities in Nigeria.

\section{Association between Educational Level and Preference to Buy, Service or Repair EEE}

\section{Cross-tabulation}

Based on the cross-tabulation as shown in Table 2, it was observed that respondents with tertiary education scored the highest percentage among other categories about their preferences to buy, service or repair EEE if it malfunctions. By implication, those with a higher level of education are more informed and involved in the decision to buy, service and repair EEE. However, those having informal education seem less involved in the decision to buy, service and repair EEE as most scored less than $5 \%$. 
Ghana Journal of Development Studies, Vol. 16 (3)

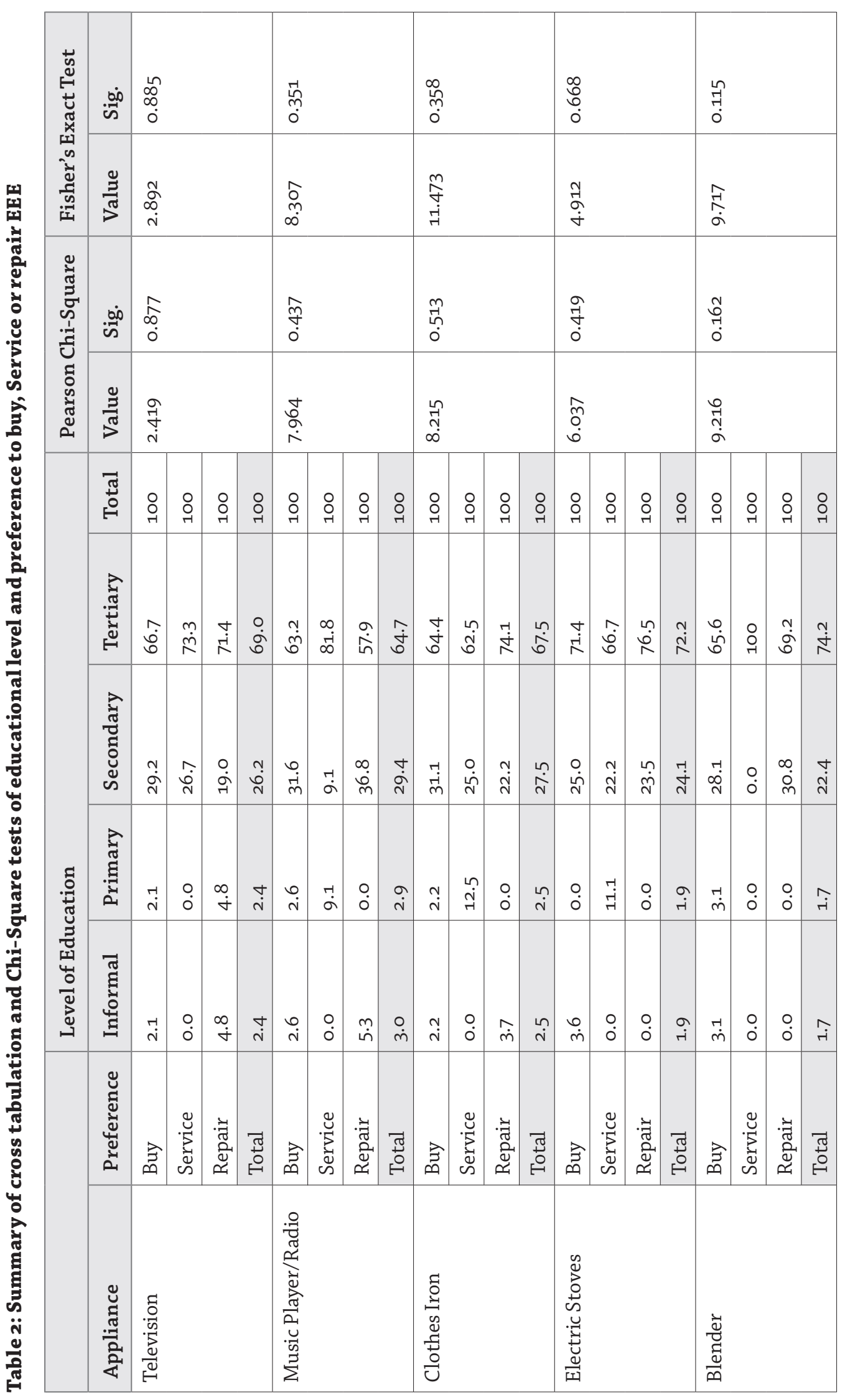


Ghana Journal of Development Studies, Vol. 16 (3)

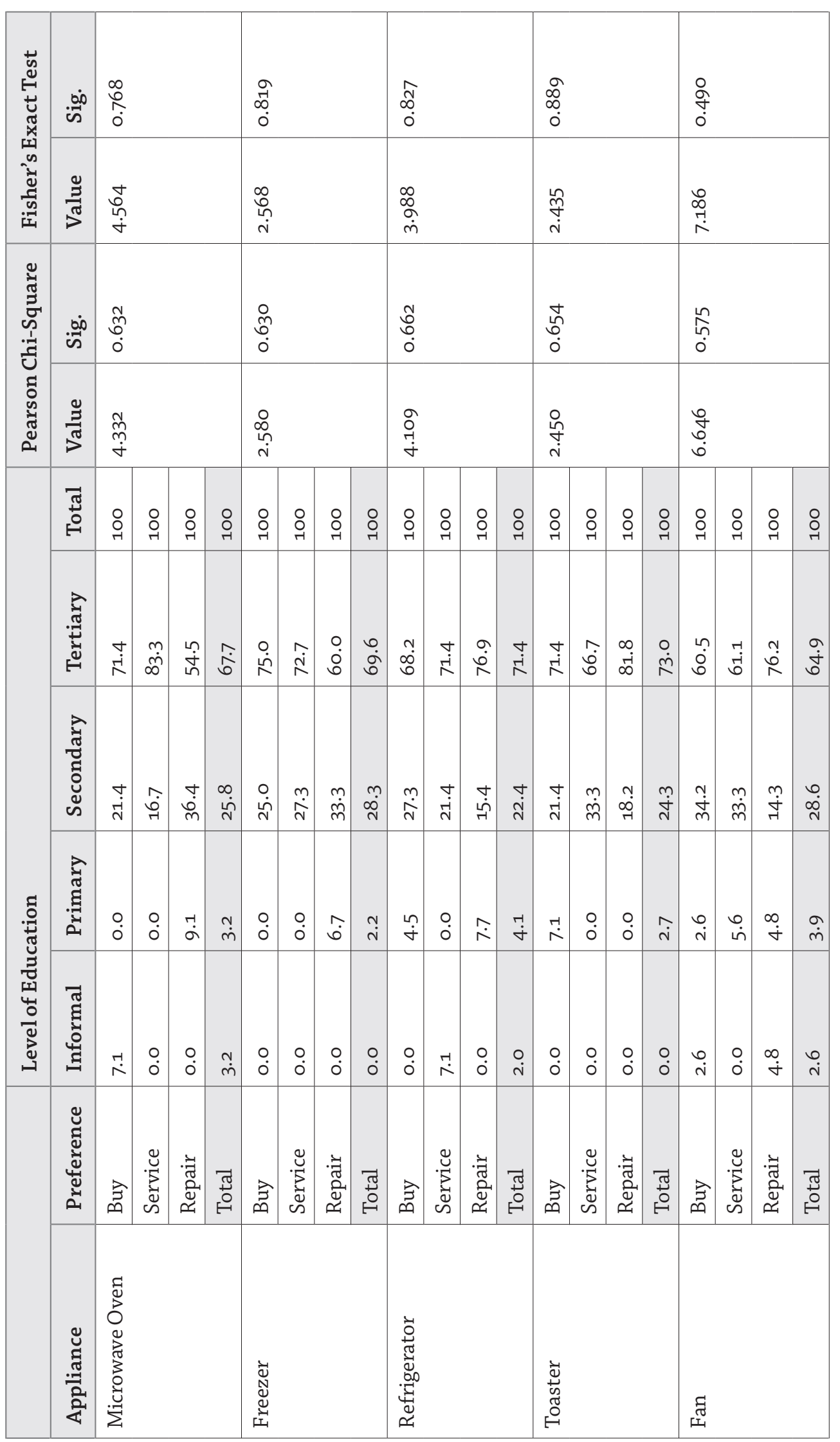


Ghana Journal of Development Studies, Vol. 16 (3)

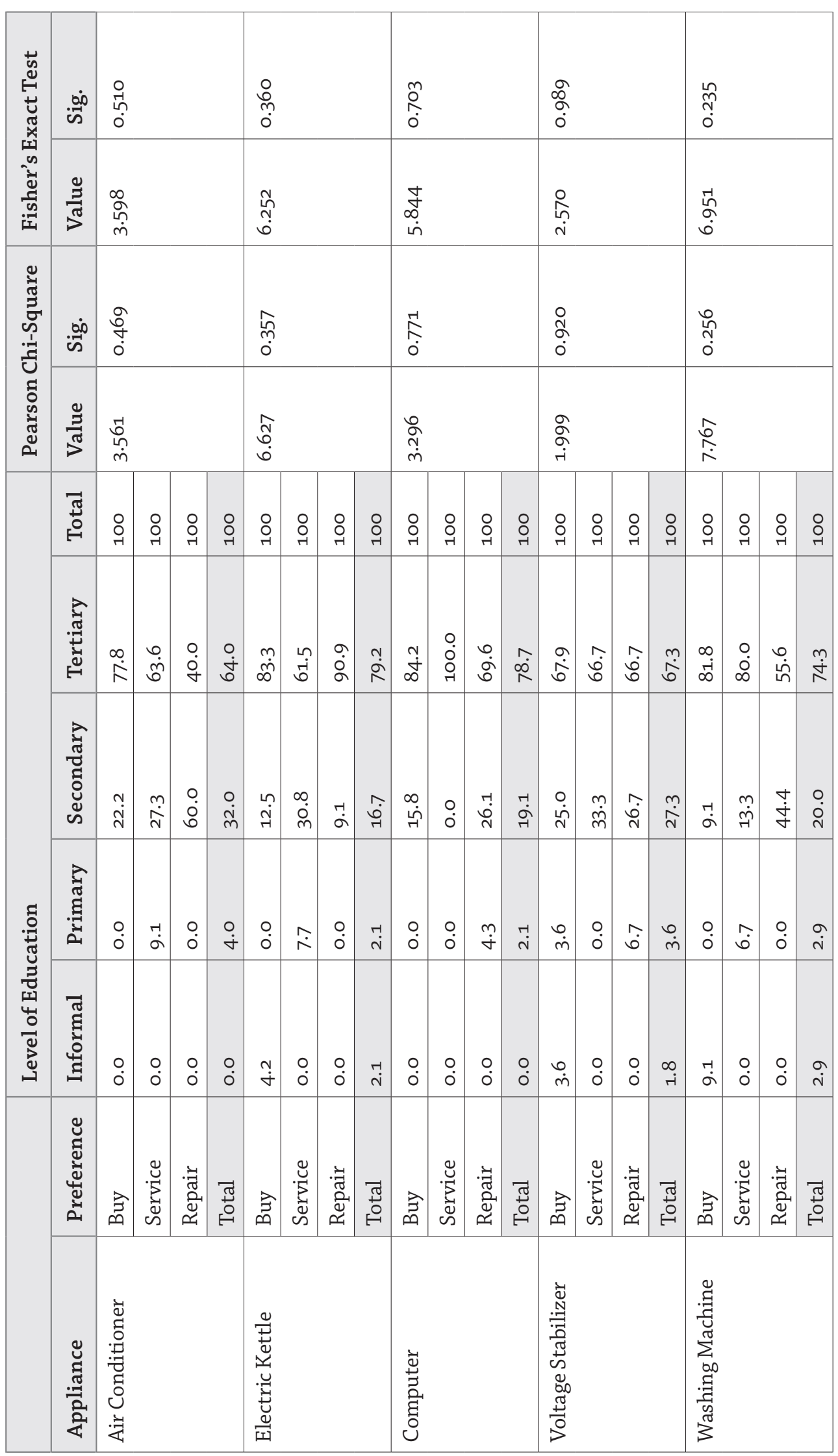


Ghana Journal of Development Studies, Vol. 16 (3)

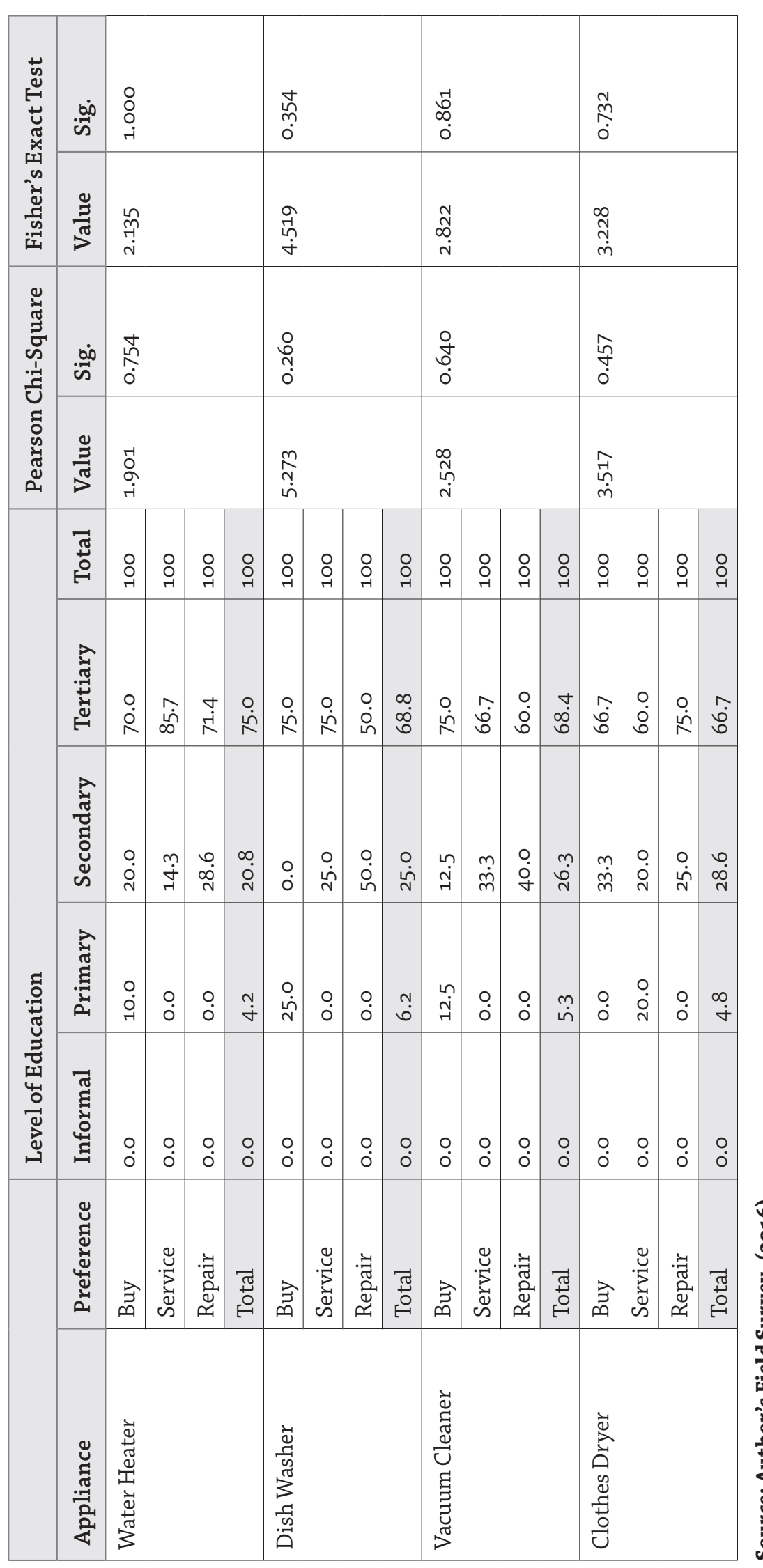




\section{Test I}

$\mathbf{H}_{\mathrm{o}}$ : There is no statistical relationship between the level of education and preference to buy, service or repair EEE

Table 2 presents the observed statistical relationship between the distribution of a categorical variable (level of education of respondents) with the distribution in another independent group of variables (preference to buy, service or repair EEE appliance) through the use of Chi-Square tests (Pearson Chi-Square Test and Fisher's Exact Test). The Chi-Square tests were used to perform an independency test, that is, the level of association and variation between the categorical variable and groups of independent variables.

Further investigations were conducted to establish possible statistical relationship between the level of education and preference to buy, service or repair EEE using Chi-Square tests (both the Pearson Chi-Square Test and Fisher's Exact Test). Results showed that none of the independent group of variables is related or associated with the categorical variable. It was observed that all the cases were not statistically significant as the calculated P-value of both the Pearson Chi-square Test and Fisher's Exact Test were greater than the table value of 0.05 (Table 2). Hence the rejection of the null hypothesis that states that there is no statistical relationship between the level of education and preference to buy, service or repair EEE. It can be implied that the level of education of respondents does not in any way determine the preference of respondents in buying, servicing or repairing EEE in the study area.

\section{Association between Income and Preference to Buy, Service or Repair EEE}

\section{Cross-tabulation}

From Table 3, an examination of cross-tabulation of the variables of income and preference to buy, service or repair EEE indicate income is a determinant regarding preference to buy, service or repair EEE. For instance, the larger percentage of respondents with earning above $\mathrm{N} 120,000$ prefer to buy rather than service or repair EEE if it malfunctions. The results also indicated that as income decreases, there was a general decline in preference to buying with the larger percentage of households showing a preference for servicing EEE, and then repairing EEE. 
Ghana Journal of Development Studies, Vol. 16 (3)

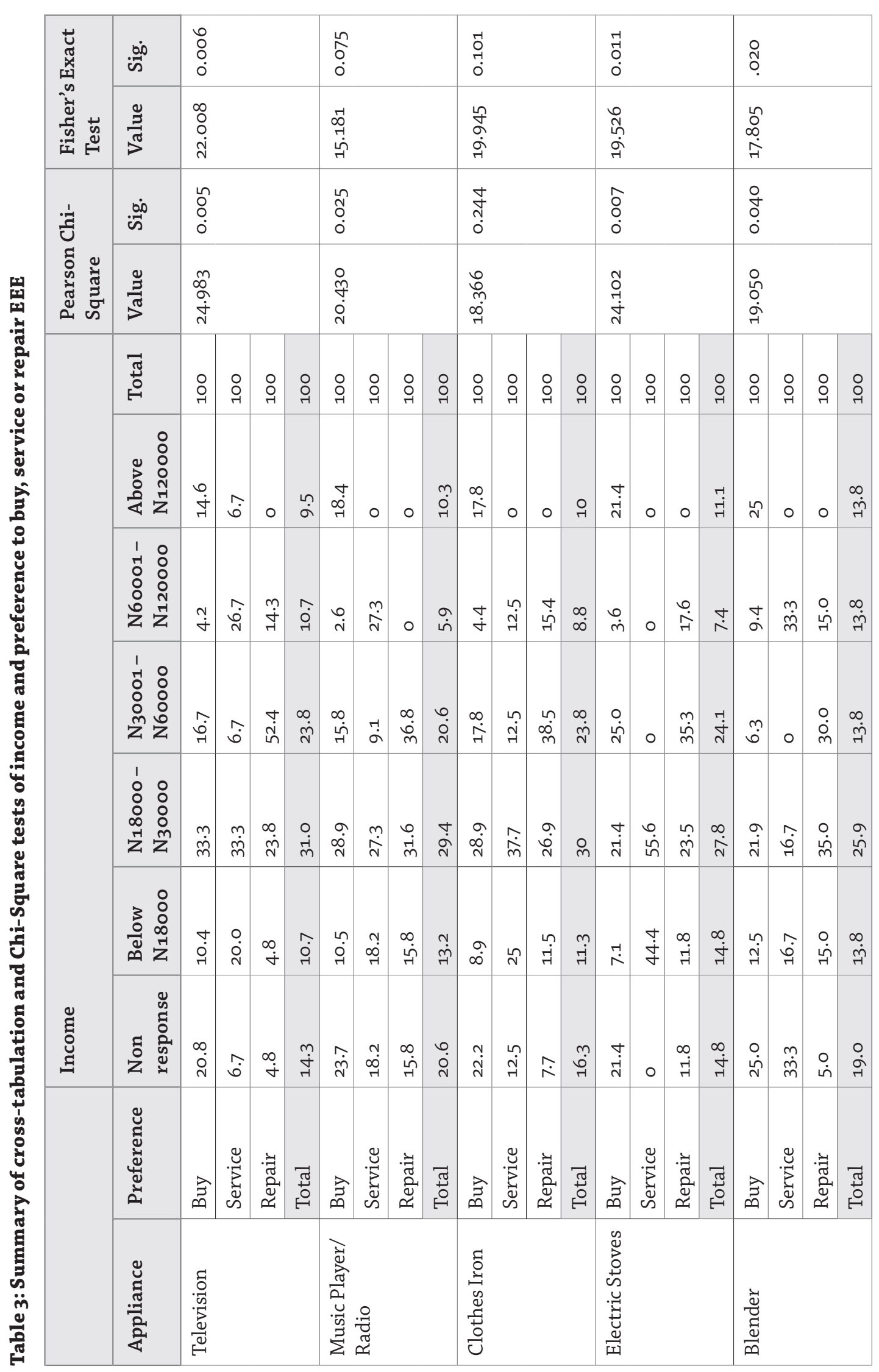


Ghana Journal of Development Studies, Vol. 16 (3)

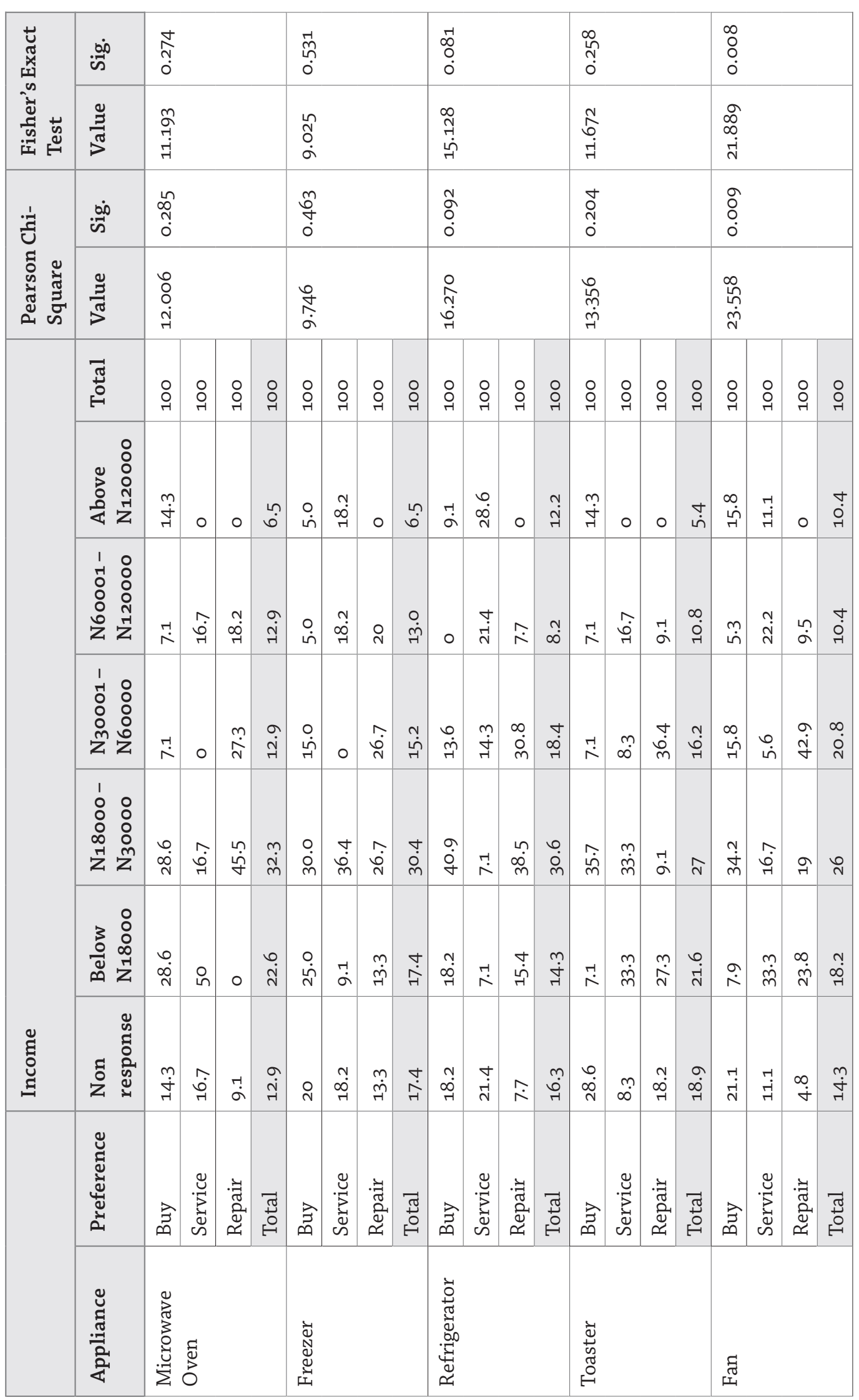


Ghana Journal of Development Studies, Vol. 16 (3)

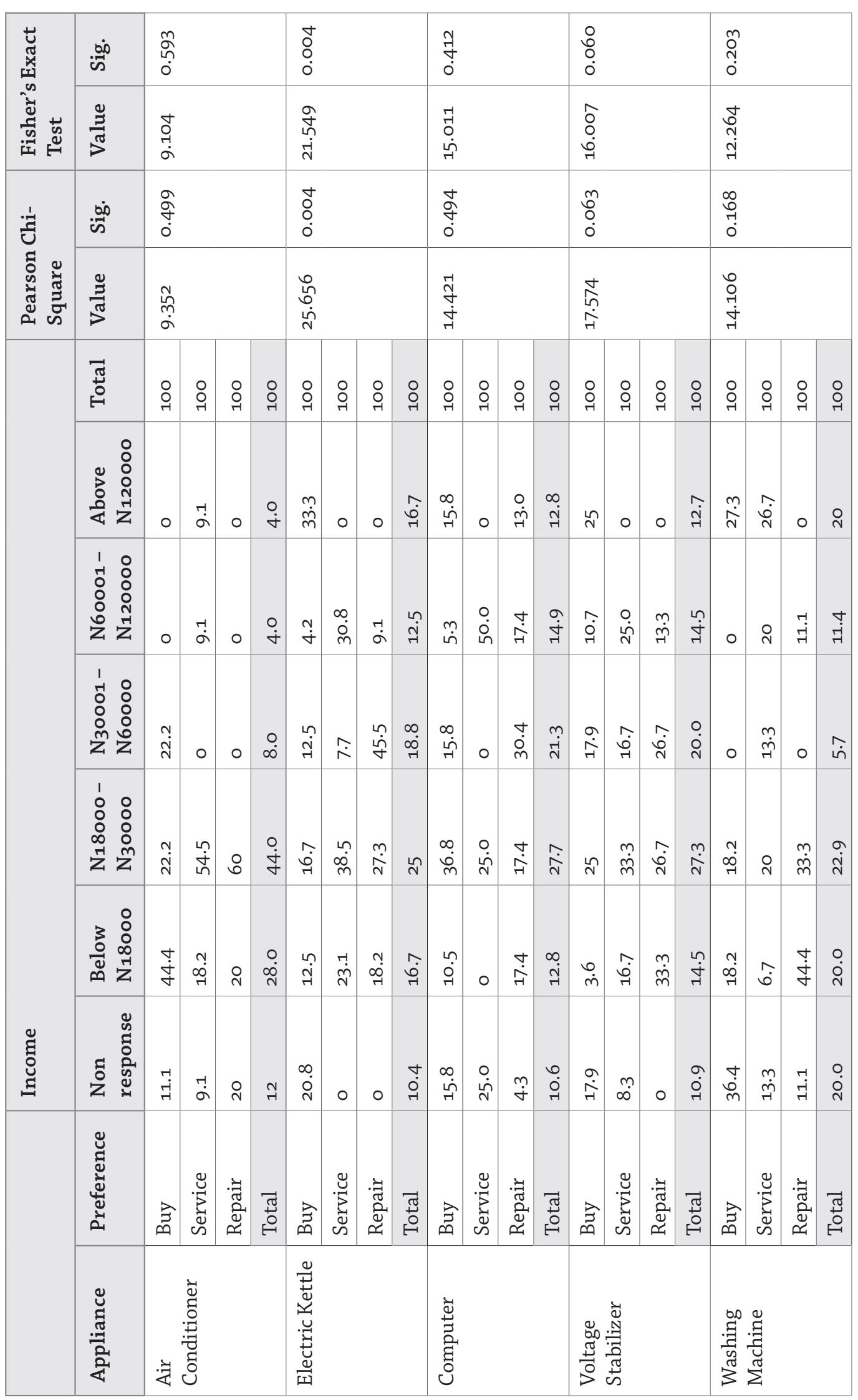


Ghana Journal of Development Studies, Vol. 16 (3)

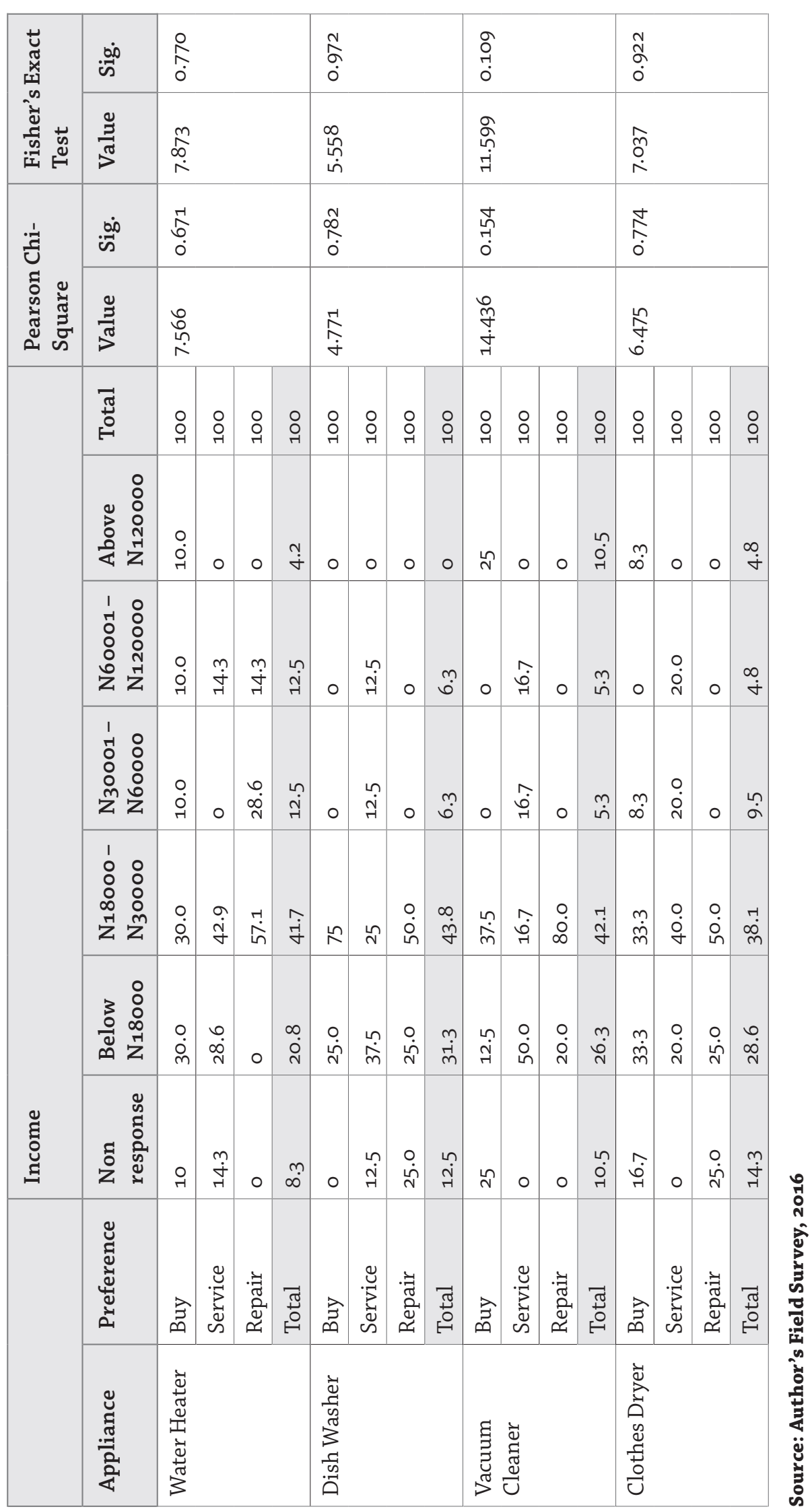




\section{Test II}

$\mathbf{H}_{\mathrm{o}}$ : There is no statistical relationship between Income and preference to buy, service or repair EEE

Also, in the quest to determine which of the socioeconomic variables of the respondents influences the preference to buying, servicing and repairing EEE, further investigations were again conducted to establish relationship between respondents' average income (categorical variables) and preference to buy, service or repair EEE (independent group of variables) in Table 3.

From Table 3, the results of the Pearson Chi-square Test show that seven (7) out of the nineteen (19) independent groups of variables were statistically associated with the average income. They are television ( $\mathrm{P}=0.005)$, electric kettle $(\mathrm{P}=0.004)$ and fan $(P=0.009)$ while others have calculated significant values greater than table value of 0.05 . By implication of the Pearson Chi-square Test result, the categorical variable income of respondents is statistically associated and influences the preference to buy, service or repair of EEE such as the television, music player/radio, electronic stoves, blender, fan, electronic kettle and voltage stabilizer. Besides, the Fisher's Exact Test statistics results observed agree with the Pearson Chi-square Test results presented and observed in Table 3 for the relationship between income and preference to buy, service or repair EEE were the same. The Fisher's Exact Test results show that television $(\mathrm{P}=0.006)$, electric stoves $(\mathrm{P}=0.011)$, blender $(\mathrm{P}=0.020)$, fan $(\mathrm{P}=0.008)$ and electric kettle $(\mathrm{P}=0.004)$ were statistically influenced by the income of respondents. Hence, based on Fisher's Exact Test observed result, the income is statistically associated with the preference of the respondents' preference in buying, servicing or repairing EEE.

By implication, the results from both the Pearson Chi-square Test and the Fisher's Exact Test statistic show that there is an association between income and preference to buy, service or repair EEE. Thus, it is concluded that respondents' income statistically influences the preference to buy, service or repair EEE. In other words, of the socio-economic variables of respondents, income is a major categorical variable that determines the preference to buy, service or repair EEE.

\section{CONCLUSIONS AND RECOMMENDATIONS}

This paper investigated households' consumption of EEE in Ota, Nigeria. The findings revealed that households use various appliances, with television as the most common household EEE, owned by $85.6 \%$ of households. The dishwasher was the least used. The EEE consumption rate among the households as revealed by this study suggests necessity seems a crucial factor to EEE consumption. 
It was found that most ( $82 \%$ ) households acquired their EEE as new products. Although the majority (68.6\%) of households rated their EEE to be in good condition, about $46 \%$ preferred to buy new EEE rather than service or repair what they owned. These consumption habits indicate a potential increase in WEEE generation, and more importantly suggest the replication of throw-away society in the study area as currently is the case in the developed countries. This unsustainable consumption will have implications for WEEE management and environmental degradation in Ota.

Moreover, the mean percentage $(58.0 \%)$ of households considered convenience more crucial in the acquisition of EEE than other factors such as relatives, friends, advertising, increased income, and neighbours. It can, therefore, be concluded from the study that convenience is a significant factor as a determinant of EEE consumption than affordability and advertising.

The study revealed different approaches to disposal of old EEE are obtainable in Ota. $12.6 \%$ offered their old EEE for sale, $14.2 \%$ as gifts, $0.7 \%$ retained old EEE for occasional use and $20.3 \%$ threw away theirs. While majority (52.2\%) claimed they had no issues with the disposal of their old EEE since they newly acquired them, the percentage of households that threw away their old EEE deserve a closer examination if throwaway habit must be discouraged among households.

The Chi-Square Tests results established that income has influence on the preference to buy, service or repair EEE. This is at variance with test results for statistical relationship between educational level and preference to buy, service or repair EEE.

This study revealed the prevailing situation regarding EEE consumption in Ota, Nigeria. It is noteworthy that this study focused on the households alone and did not capture the consumption attributes of other sources such as businesses and institutions. Consequently, this study recommends the extension of the research to other identified sources to have a holistic picture of the EEE consumption and WEEE generation in the study area. It is believed that the outcome of such research would assist in the review of extant WEEE policies in Nigeria. For instance, the Environmental (Electrical/Electronic Sector) Regulation 2011 has been in operation for almost a decade in Nigeria. The National Environmental Standards and Regulation Enforcement Agency (NESREA) should ensure the proposed review of the extant regulation to address unsustainable consumption of EEE already happening in Ota. The proposed review should maximise the research outcomes of EEE consumption and management studies and feedbacks from the implementation of the regulation hitherto. For a successful actualisation of proposed review of the WEEE policies, stakeholders, consisting of consumers (householders, businesses, 
and institutions) and EEE manufacturers responsible for WEEE generation should be engaged in inclusive WEEE planning and management. As advocated by Adamu (2013), there is a need to find a balance between demand and supply for EEE. Regulating the market for EEE would help reduce the quantity of exports from the developed countries that have been responsible for the supply of both the new EEE and UEEE.

\section{REFERENCES}

Adamu, L.M. (2013). Reducing the cost of wastes from electrical and electronic equipment - A case in four cities of Ethiopia. Master's Thesis, Swedish University of Agricultural Sciences, Uppsala. Available online at: http://stud. epsilon.slu.se/6382/1/Adamu_L_M_140122.pdf

Adediran, Y.A. and Abdulkarim, A. (2012). Challenges of electronic waste management in Nigeria. International Journal of Advances in Engineering and Technology, 4(1), pp. 640-648.

Adesina, O.S. (2012). The negative impact of globalization on Nigeria. International Journal of Humanities and Social Science,2, pp. 193-201.

Arora, R. (2008). Best practices for e-waste management in developing nations. Available online at :https://smallb.sidbi.in/sites/default/files/knowledge base/best practicesforEwasteManagementdevelopingnations.pdf

Balde, C.P., Wang, F., Kuehr, R. and Huisman, J. (2015). The global e-waste monitor2014. Bonn, Germany: United Nations University, IAS - SCYCLE.

Chukwudebe, G.A. and Diala, U.H.(2014). The African e-waste problems: Imperatives for an eco-friendly management system. Available online at:http://www.nse. org.ng/pic_uploaded/resources/o7A2-5MainPaper-EWaste_Conference.pdf [Accessed 10 September 2016].

Enger, E.D. and Smith, B.F.(2002). Environmental science: A study of interrelationship (8th ed). Boston: McGraw-Hill Companies, pp. 401-416.

Glaubitz, J. P. A. (2011). Modern consumerism and the waste problem. Available online at:http://users.physik.fu-berlin.de/ glaubitz/mnses910o_essay.pdf[Accessed 18 July 2016]

Gutberlet, J. (2003). Cities, consumption, and the generation of waste, In Aviso, Information Bulletin on Global Environmental Change and Human Security. Available online at: http://unpan1.un.org/intradoc/groups/public/documents/ apcity/unpano37034.pdf [Accessed 12 August 2016]. 
Herat, S. (2009). Electronic waste: An emerging issue in solid waste management in Australia. International Journal of Environment and Waste Management, 3(1/2), pp. 1-30.

Ibrahim, F.B., Adie, D.B., Giwa, A. and Okuofu, C.A. (2014). Study of material flow of end-of-Life computer equipment (e-wastes) in some major cities in Nigeria. Nigerian Journal of Technological Development,11 (2), pp. 44-52.

Joines, J.(2012). Globalization of E-waste and the consequence of development: A case study of China. Journal of Social Justice ,2, pp. 1-15.

Kalana, J.A. (2010). Electrical and electronic waste management practice by households in ShaAlam, Selangor, Malaysia. International Journal of Environmental Sciences,1, pp. 132-144.

Katagishi, M., Yamamoto, K., Suka, H. and T. Yoshida, T. (2011). Home electronics and appliances for environmentally conscious lifestyles. Hitachi Review, 6o,pp. 316-323.

Kumar, R. and Holuszko, M. (2016). Electronic waste and existing processing routes: A Canadian perspective. Resources, 5(35).pp.1-19 Doi:10.339o/resources6040035

Magalini, F., Kuehr, R. andBalde, C.P. (2015). eWaste in Latin America statistical analysis and policy recommendations. Available online at: https://www.gsma. com/latinamerica/wpcontent/uploads/2015/11/gsma-unu-ewaste2015-eng. $\mathrm{pdf}$

Manhart, A., Osibanjo, O., Aderinto, A. and Prakash, S. (2011). Informal e-waste management in Lagos, Nigeria - socio-economic impacts and feasibility of international recycling co-operations. Final report of component 3 of the UNEP SBC E-waste Africa Project. Available online at: http://www.basel. int/Portals/4/Basel\%20 Convention/docs/eWaste/Ewaste_Africa_Project_ Nigeria.pdf[Accessed on 10 September 2016].

Mburu, P.T. and Tuduetso, T.(2013). Investigation of consumer behavior on discarding of their electrical/electronic waste: A case of Gaborone city. Journal of Business Management and Economics, 4, pp. 200-205.

Mihai, F. and Gnoni, M. (2016). E-waste management as a global challenge (introductory chapter). Available online at: http://dx.doi.org/10.5772/64596 [Accessed 4 September 2016].

Nnorom, I.C. and Osibanjo, O.(2008). Electronic waste (e-waste): Material flows and management practices in Nigeria. Waste Management, 28, pp. 1472-1479.

Ogungbuyi, O., Nnorom, I.C., Osibanjo, O. and Schluep, M. (2012). e-Waste country assessment Nigeria (e-Waste Africa project of the Secretariat of 
the Basel Convention). Available online at: http://ewasteguide.info/files/ Ogungbuyi_2012_BCCC-Empa.pdf

Ogunseye, N.O. and Kadiri, W.A. (2016). Households' consumption lifestyles and implication for climate change: Case study of Ota, Nigeria.Presentation at the 7 th Annual Ibadan Sustainable Development Summit (ISDS 2016) held at Centre for Sustainable Development, University of Ibadan, Ibadan, 21st-26th August.

Ogun State Government (2008).Ogun State Regional Plan (2005-2025) Final Report. Lagos: CPMI Limited.

Ojeda-Benitez, S., Cruz-Sotelo, S.E., Velázquez, L., Santillán-Soto, N., Nuñez, M.Q., Cueto, O.R.G., and Markus, W. (2013). Electrical and electronic waste in Northwest Mexico. Journal of Environmental Protection, 4, pp. 405-410.

Olukanni, D.O., Akinyinka, O.O., Ede, A.N., Akinwunmi, I.I. and Ajanaku, K.O. (2014). Appraisal of municipal solid waste management, its effect and resource potential in a semi-urban city; a case study. Journal of South African Business Research, 2014, pp. 1-13.

Omole D.O., Tenebe I.T., Emenike C.P., Umoh, A.S. and Badejo, A.A. (2015). Causes, impact and management of electronic wastes: Case study of some Nigerian communities. ARPN Journal of Engineering and Applied Sciences, 10,pp. 78767884 .

Osibanjo, O. (2012). Enhancingenvironmentallysoundmanagementonwasteelectrical and electronic equipment (WEEE) in Africa. A discussion paper with Mario Yarto. Available online at: www.basel.org.ng/index.php/conferenceabstracts/ doc_downloads/65-phase-2-e-waste-africa-project[Accessed 10 September, 2016].

Perez-Belis, V., Bovea, M.D. and Ibanez-Fores, V.(2015). An in-depth literature review of the waste electrical and electronic equipment context. Trends and evolution. Waste Management \& Research, 33(1), pp. 3-29.

Pitcher, G. (2015). Beating the binsters. Available online athttps://www.teleplan.com/ manage/wp-content/uploads/New-Electronics-Article.pdf [Accessed 18 July 2016].

Rees, G. (2009). Throwaway society. BBC Learning English. Available online at http:// downloads.bbc.co.uk/worldservice/learningenglish/ask_about_english/ pdfs/aae_090217_throw away.pdf

Ruiz, S.N., Castro, H.N., Berra, A.V. and Perez, M.G. (2012). Recycling of waste electrical and electronic equipment as a strategic line tangential of circular economy. European Scientific Journal,11,pp.66-77. 
Salako, R.A. (2009).Ota: Biography of the Foremost Awori Town. Ota: Penink Publicity.

Stefansdotter, A., Knusden, J.S., Flack, M. and Hansen, P.G. (2016). Nudging for sustainable consumption of electronics. Summary Report. Denmark: Nordic Council of Ministers. Available online at: https://norden.diva-portal.org/ smash/get/diva2:943627/FULLTEXTo1.pdf

Terada, C. (2012). Recycling electronic waste in Nigeria: Putting environmental and human rights at risk. Northwestern Journal of International Human Rights, 10,pp. 154-171.

Terazono, A., Murakami, S., Abe, N., Inanc, B., Moriguchi, Y., Sakai, S., Kojima, M., Yoshida, A., Li, J., Wong, J. Y. M. H., Jain, A., Peralta, I.-S. K. G. L., Mungcharoen, C.-C. L. T., and Williams, E. (2006). Current status and research on e-waste issues in Asia. J Meter Cycles Waste Manag, 8, pp. 1-12.

Tong, X. and Wang, J. (2012). The shadows of the global network: E-waste flows to China, In C. Alexander and J. Reno (Eds.) Economics of Recycling: The Global Transformation of Materials, Values and Social Relations, pp. 98-118. London: Zed Books.

Veit, H.M. andBernardes, A.M. (2015). Electronic waste: Generation and management, In H.M. Veit and A.M. Bernardes (Eds.) Electronic waste, topics in mining, metallurgy and materials engineering. Switzerland: Springer International Publishingpp.3-12. 